
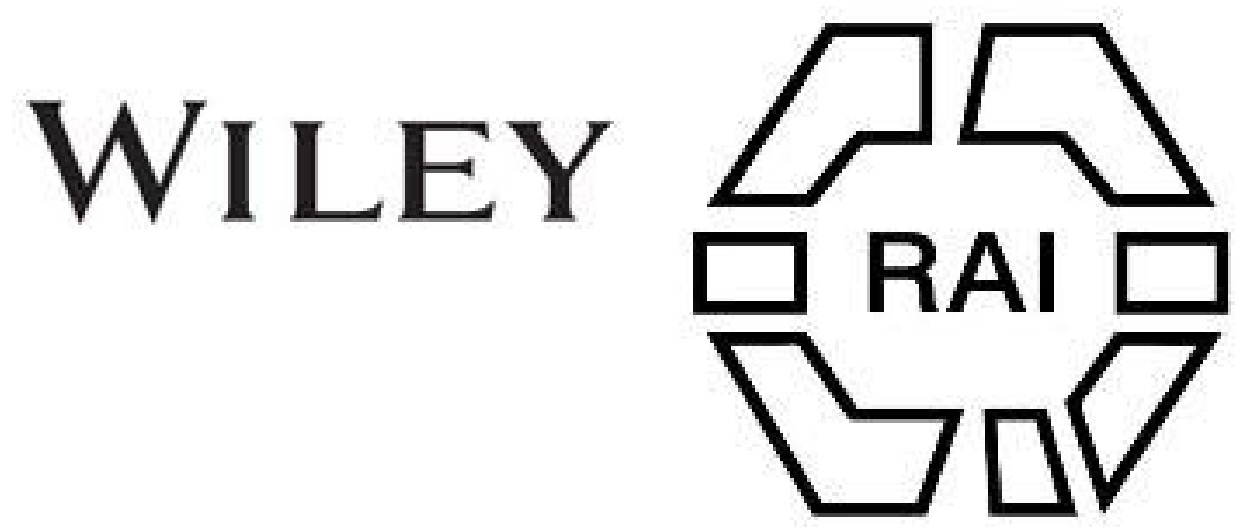

\title{
97. Cross Cousin Marriage in South India
}

\section{Author(s): F. J. Richards}

Source: Man, Vol. 14 (1914), pp. 194-198

Published by: Royal Anthropological Institute of Great Britain and Ireland

Stable URL: http://www.jstor.org/stable/2787822

Accessed: 26-06-2016 21:11 UTC

Your use of the JSTOR archive indicates your acceptance of the Terms \& Conditions of Use, available at

http://about.jstor.org/terms

JSTOR is a not-for-profit service that helps scholars, researchers, and students discover, use, and build upon a wide range of content in a trusted digital archive. We use information technology and tools to increase productivity and facilitate new forms of scholarship. For more information about JSTOR, please contact support@jstor.org.

Wiley, Royal Anthropological Institute of Great Britain and Ireland are collaborating with JSTOR to digitize, preserve and extend access to Man 
kill pigs. If the inhabitants see him do so they know he has presented a kava to the chief. If any man reproaches him for killing their pigs that man will die, because the visitor has presented a kava and the tevoro (= kalou) has seized it, that is why the tevoro is mana.* On the other hand, if the kava has not been presented the visitor may not touch anything. "What often makes us ill is that no " presentation has been made. Tauvu-ship is exceedingly mana amongst us."

Etonia, of the same tribe, also declares that the tevoro would kill a man who seized property without previously offering kava in the shape of a whale's tooth.

Namuka is tauvu to Mbau as well as to Dhakaundrove. If the Mbauans came to Namuka, although they were the noblest state in Fiji they could not fly a flag, $\dagger$ but came and made an offering to the "Two Mbi" (Ko i rau na Mbi) kalou of Namuka. In the same way, if the Namukans went to Mbau they kept quiet until they had presented first-fruits (isevusevu) with the prayer, "Let us live, let us not die." Then all respect (vakarokoroko) was at an end and they killed fowls and pigs.

The two tribes therefore recognise each other's kalou, and this explains the persistent assertion that they have the same kalou.

The reader will notice that though a whale's tooth is presented it is called "kava." Evidently kava was once the right and proper offering. Now Vanua Levu is also the home of kava chants, if not of the whole Fijian kava ceremonial. In a chant sung over the kava at the installation of the chief of Korodhau, in the tribe of Dhakaundrove, there occurs a line: "Namuka is a foolish country." This insulting of the tauvu is an important feature of tauvu-ship, as we have seen; indeed, some tribes will tell you they are tauvu to such and such a tribe because their ancestors insulted each other. It is more than a mere licence, it is almost a duty. In Korodhau we find it as a rite.

We may suppose that the kava presented by the visitor was chewed and brewed with the accompaniment of the kava chant, and that this chant contained an insult to the tauvu, which ritually inaugurated the licence of speech and action which is part of the tauvu-ship.

I do not think anything more is to be got out of Fiji. The neighbouring Polynesian islands do not know this institution, though they have customs connected with the sister's son. For further clues we must look to the lands to the west of Fiji.

A. M. HOCART.

India, South.

Richards.

\section{Cross Cousin Marriage in South India. By $F$. J. Richards.}

In most of the castes of South India the most suitable bride for a boy is considered to be his maternal uncle's daughter. His paternal aunt's daughter is next in favour, and in some castes he has a preferential right to marry the daughter of his sister. $\$$ So strong is this custom that, in some castes, if the parents of a

* To be effective, have power (of spirits and chiefs). It contains no idea of a mystic power or effluence.

$\dagger$ A subject tribe could not fly a flag on their canoe when approaching the village of their overlords or superiors.

$\ddagger$ The only other people I have visited who sing at kava are the Futunans. They have a quite modern chant which runs :

"Uvea (Wallis Is.) has a lazy disposition,

A disposition like a temonio (spirit, ghost)."

Futuna and Wallis intermarry but are not tauru. I can only explain this song as a reminiscence of tauru, or as Fijian influence, of which there is much in Futuna.

$\S$ e.g., "It's a binding custom among Korachers that the first two daughters of a woman must " be given to her brother to be married either by himself or to his sons."-Ethnographic Surrey of Mysore, VII, p. 7. 
girl whose hand can thus be claimed marry her to a man other than the relative who has this right of first refusal, they will be excommunicated from caste. A girl who is thus married by virtue of her relationship to her husband is called an "urimai girl," while one chosen to enhance her husband's position or wealth is called a "perumui (dignity) girl.* The rule, which is common among both Tamils and Telugus, is known to the latter as meñärikam.

In the Bäramahāl Records (Section III., p. 38), compiled in Salem District, at the end of the eighteenth century, and printed by the Government of Madras in 1907, the following account is given of mēnārikam as practised by the Kōmati Vaisyas :-

"If a sister has a son and her brother has a daughter, it is an invariable rule for the brother to give his daughter in marriage to his sister's son, and, let the girl be handsome or ugly, the sister's son must marry her.

"If a brother have two sisters, and the sisters have each a son, and he himself should have two daughters, he is obliged to give one of the daughters in marriage to each of his sisters' sons.

"However, if a brother should have three or more daughters, and his sisters should have a plurality of sons, the brother is only obliged to give one of his daughters to each of the eldest of his sister's sons, and he may dispose of the rest of his daughters as he pleases, and so in like manner may the sisters dispose of their younger sons.

"If the brother's daughter be blind, lame, or deformed, his sister's son must take her in marriage, but, on the contrary, if the sister's son should happen to be blind, lame, or in any shape deformed, the brother is not obliged to give his daughter in marriage to him.

"But if the sister should have a daughter and a brother a son, the sister is not obliged to give her daughter to her nephew, but may give her to whom she pleases."

The degree of rigour with which this rule is enforced varies in different castes, and sometimes it is a mere matter of form to offer the fortunate uncle or cousin the first refusal. Its rigorous application among the Kōmatis suggests that the practice of Cross Cousin Marriage in South India should be explained on economic grounds. The Kōmatis are the wealthiest caste of traders and money-lenders in South India. They claim to be true "twice-born" Vaisyas, and they imitate Brahmanic practice with extreme punctiliousness. Money-lenders, however, are seldom popular, and the zeal of the Kơmatis in pursuit of money is proverbial. Can it be that the rigidity with which they adhere to Cross Cousin Marriage is based on the mercenary interests?

Now there is abundant evidence that inheritance through females was at one time general throughout South India. It would seem that a matrilineal system of inheritance was a feature of the sub-culture of the south, on which the Brahmanic super-culture was imposed. Brahmanic culture, of course, lays vital emphasis on inheritance through males.

Assuming that inheritance through females preceded inheritance through males in South India, it is probable that the transition from one to the other was gradual. not sudden.

Under a system of inheritance through females a man has no interest whatever in finding out who his father is. When, however, the idea of paternity begins to take shape, perhaps under the influence of a superior culture, the father begins to take a paternal interest in his child. He naturally wishes to provide for the child's future, but under a matrilineal system this is impossible.

\footnotetext{
* See Mr. F. R. Hemingway's Gazetteer of Trichinopoly District, p. 94.
} 
Now under Mother Right I inherit my mother's property, but I cannot transmit the heritage to my children, for my sister and her children are my heirs. If, therefore, I wish to transmit the property I enjoy to my children, I must marry my sister's daughter.

Similarly, my father is heir to his mother, but he cannot transmit the wealth he enjoys in his own right to me, for his sister and his sister's children are his heirs. If, therefore, he wishes to provide for me out of the ancestral property, he must marry me to his sister's daughter.

So also my mother's brother cannot transmit his property to his son, for my mother and her children are his heirs. His only way out of the difficulty is to marry his son to my sister.

Under a matrilineal system in its most archaic form the actual management of property vests in females. (See J. D. Mayne, Hindu Law and Usage, 1901, p. 683.) But in course of time the eldest male member of the family came to be recognised as manager. As manager of a family, by this time "patriarchal" in all its ideas except those of inheritance, my mother's brother would find that a marriage between me (his heir) and his daughter (his wife's heir) would be the most convenient method of keeping the family property intact and providing for us both.

The subjoined diagram illustrates the difficulties of succession under Mother Right; the individuals in italics therein cannot transmit property* :-

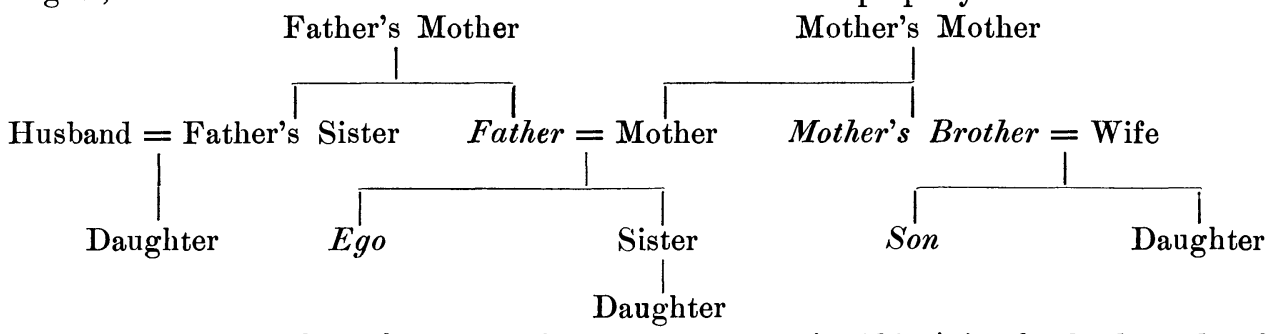

The foregoing hypothesis was formulated by me in $1909, \uparrow$ in the backwoods of South India, in complete ignorance of all that had already been written on the subject, $\ddagger$ and it was with no small surprise that I came across a precisely similar explanation of Cross Cousin Marriage as it exists in an entirely different branch of the human race. Writing of the Carrier division of the Western Déné (Athapascan) Indians of North America, $\$$ Mr. C. Hill-Tout thus describes the advantages of marrying a boy to his maternal uncle's daughter :-

"Though descent was counted exclusively on the mother's side among these tribes, the authority of the father was recognized to a considerable extent; for he had a voice in the disposal of his daughters in marriage, and frequently so arranged matters that his legal inheritor and successor-his sister's son-should marry one or more of his daughters. This was done that his offspring might share in his property, and not be wholly deprived under the clan rule of his possessions, as under their laws no hereditary property or rights could be alienated or passerl over to the members of another clan even though the recipients were the donor's own children.

* It is significant that in Tamil one word (māman) does duty for (1) wife's father, (2) maternal uncle, (3) paternal aunt's husband; and one word (machinan) for (1) brother-in-law, (2) maternal uncle's son, (3) paternal aunt's son; while the feminine form of the latter word (machini) stands for (1) sister-in-law, (2) wife's younger sister, (3) younger brother's wife, (4) maternal uncle's daughter, and (5) paternal aunt's daughter. $C f$. Dr. Rivers, The Todas, p. 483 sq.; and L. H. Morgan, Ancient Society, 1907, p. 447 sq.

$\dagger$ Journ. of the Mythic Suciety, Bangalore, October 1909, p. 40.

$\ddagger$ E.g.. Dr. Rivers, in Jras, 1907, pp. 611-40, and Mr. A. E. Crawley, in the Tylor Festschrift, 1907.

§ The Natives of British North America, 1907, p. 145. 
These laws and regulations were very strictly observed among the Carriers, and hence the practice of marrying the girl to her first cousin on her father's side."

There are several other customs prevalent in South India which seem to corroborate the "economic" explanation of mēnãrikam.

1. Marriage of an adult woman to an immature boy. This practice, as observed among the Malaiyālis of the Kolli-malais of Salem District, is thus described by Mr. H. Lefanu* :-

"'The sons, when mere children, are married to mature females, and the fatherin-law of the bride assumes the performance of the procreative function, thus assuring for himself and his son a descendant to take them out of Put. $\dagger$ When the putative father comes of age, and in their turn his wife's male offspring are married, he performs for them the same office which his father did for him."

This practice is not confined to the Malaiyālis, for it is recorded of several of the Tamil castes of the Plains, all of whom, like the Malaiyālis themselves, observe patrilineal succession. The existence of this practice is emphatically denied at the present day by most of the castes of whom it is recorded, and it is probable that it will yield before long (if it has not already done so) to the pressure of a more enlightened public opinion, and vanish. But that it existed within the last half century over a large area and among widely different communities is certain.

Now, in the first place it must be noted that this practice, whenever it occurs, is invariably associated with Cross Cousin Marriage, though comparatively few of the meñärikam-observing castes carry their principles to such extreme lengths.

In the second place, fatherhood, in communities where the practice prevails, is as purely a legal fiction as it is under the Brahmanic system of Adoption, and in both cases the fictitious sonship conveys strong economic interests.

Mr. Hill-Tout again furnishes a striking analogy to this practice in his account of the matrilineal Western Nahane section of the Déné Indiansf:-

"A father often married his son to his own sister, that is, to the boy's aunt, without taking into account the disparity of their ages, for she may be fifty and he but fifteen. There was a special object in this ; it permitted the father to pass over, through his sister, his own property and belongings to his own son, which under the matrilineal rule could not be otherwise done; a man's own children not inheriting any of his property because they did not belong to his clan."

2. Among the Malaiyālis a woman is free to leave her husband and live with her paramour, but any children she bears to her paramour are regarded as the children of her lawful husband, who can claim them as his own, and who is responsible for their maintenance. This practice finds a close parallel in the customs of the Todas, recorded on p. 546 of Dr. Rivers' classic work on that interesting people. The leniency with which such concubinage is treated is strongly polyandric in tone, and is suggestive of Nāyar sambandams, but Nāyars observe matrilineal succession, while Malaiyālis and Todas are definitely patrilineal. It is not easy to explain the interest of a husband in his wife's illicit progeny, except on economic grounds.

3. Another practice not uncommon among the Telugus and Kanarese is that of "affiliating a son-in-law," commonly known as illātam. Failing male issue, a father is at liberty to marry his daughter to a man who agrees to become a member of the family, and who thereafter resides in the father-in-law's house and inherits the estate for his children.

4. The practice of dedicating the eldest daughter as a Basavi (dancing girl),

* In his Salem District Manual.

†Putra (son) $=$ Put (hell) and ra (save); "one who saves from hell"; a choice freak o Sanscrit philosophy.

$\ddagger$ The Natives of British North America, p. 182. 
about which so much has been written, is perhaps intended to serve a similar purpose, for a Basavi is entitled to inherit her father's property as a son, and to transmit it to her offspring.

I do not claim to have solved the problem of Cross Cousin Marriage in all its manifestations. I am fully aware that my economic hypothesis is not novel. I submit, however, that the evidence recited suggests :

(1) That, in South India, economic considerations and, in particular, the transmission of "family property,"* exercise a very material influence on marriage relationships;

(2) That the growth of "paternal feeling" is inconsistent with and inimical to the continuance of matrilineal succession;

(3) That the intrusion of a strongly patrilineal culture, such as the Brahmanic culture undoubtedly is, into a matrilineal sub-culture would tend to subvert the economic foundations of society by the disruption of "family property";

(4) That in a matrilineal community one of the main advantages of patrilineal transmission of property, viz., the gratification of the natural desire of a father to provide for his offspring, may be effectively secured by insisting that a man should marry the daughter of either his maternal uncle, his paternal aunt, or his sister; and

(5) That the same rule would enable a matrilineal community to conform to a patrilineal system of inheritance without fear of dissipating the family property, the integrity of which is dependent on the continuance of inheritance on matrilineal lines.

In other words, the rule which gives a man the first refusal of his sister's, his maternal uncle's, or his paternal aunt's daughter in marriage may be interpreted as a sort of compromise between matrilineal succession and Brahmanic law ; it preserves inviolate the principles of matrilineal inheritance under patrilineal forms.

F. J. RICHARDS.

\section{Biography.}

The Life and Work of N. N. Miklukho-Maklay. Czaplička.

Czaplička.

The year 1913 being the twenty-fifth anniversary of the death of Nikholas, son of Nikholas Miklukho-Maklay, one of the most thorough and indefatigable of the scientific travellers of his day, Mr. N. A. Yanchuk, of the Imperial Society of Friends of Natural Science, Anthropology, and Ethnography of Moscow University, undertook the task of presenting a fairly full account of his life and work in a pamphlet $\dagger$ recently published in St. Petersburg. As most of the areas visited by him are under British rule, and as hitherto more of his work has been published in French, German, and English than in Russian, it will undoubtedly be of great value to English scientific workers of the present day to be acquainted with the information thus given to the public.

Miklukho-Maklay was of Little Russian nationality, son of a Cossack, $\ddagger$ and born in 1846, in the government of Novgorod. He was educated in Petersburg, studying law at the University, but before he had completed his course he went to Germany,

* It would be incorrect to speak of "clan property" in South India, as the Brahmanic practice of Partition almost everywhere has broken up the clan (= exogamous group) into numberless joint families, and the joint family is now the economic unit.

$\dagger$ "Nikholai Nikholaievich Miklukho-Maklay and his Scientific Work," by N. Y. Yanchuk. St. Petersburg, 1913 (in Russian).

$\ddagger$ This does not refer to Cossack regiments of the present day, but to the original free and independent military community of Cossacks. 